\title{
KEEFEKTIFAN BEBERAPA SPESIES Trichoderma DALAM MENGENDALIKAN PENYAKIT ANTRAKNOSA (Colletotrichum musae) PADA BUAH PISANG CAVENDISH
}

\author{
Senja Aklirinhua ${ }^{1}$, Efri $^{2}$, \& Joko Prasetyo ${ }^{2}$ \\ ${ }^{1}$ Mahasiswa Agroteknologi ${ }^{2}$ Dosen Jurusan Agroteknologi, Fakultas Pertanian Universitas Lampung, \\ Jln. Prof. Soemantri Brodjonegoro, No. 1, Bandar Lampung 35145
}

\begin{abstract}
ABSTRAK
Percobaan ini bertujuan untuk mengetahui keefektifan beberapa spesies Trichoderma dalam mengendalikan Colletotrichum musae, penyebab penyakit antraknosa pada buah pisang cavendish. Percobaan dilaksanakan di Laboratorium Penyakit Tumbuhan, Fakultas Pertanian, Universitas Lampung, dari bulan Mei sampai dengan bulan Juni 2014. Percobaan dilakukan dengan 2 tahap yaitu secara in vitro dan in vivo. Percobaan disusun dalam Rancangan Acak Lengkap (RAL) dengan 4 perlakuan dan 6 ulangan, yaitu Kontrol, Trichoderma viride, Trichoderma koningii, dan Trichoderma harzianum. Pengamatan dilakukan setiap hari selama 10 hari. Peubah yang diamati adalah persentase penghambatan dan keparahan penyakit. Data dianalisis menggunakan analisis ragam dan dilanjutkan dengan Uji BNT pada taraf nyata $1 \%$. Hasil pengujian secara in vitro dan in vivo, perlakuanT. viride, T. koningii, dan T. harzianum. efektif menghambat pertumbuhan koloni jamur $C$. musae serta intensitas penyakit antraknosa.T. viride, $T$. koningii, dan $T$. harzianum memiliki kemampuan yang sama dalam menghambat pertumbuhan koloni jamur C. musae, baik secara in vitro maupun secara in vivo.
\end{abstract}

Kata kunci : Colletotrichum musae, Trichoderma harzianum, Trichoderma koningii, Trichoderma viride.

\section{PENDAHULUAN}

Pisang (Musa paradisiaca L.) adalah tanaman hortikultura berupa herba yang berasal dari kawasan Asia Tenggara (termasuk Indonesia). Tanaman inikemudian menyebar ke Afrika (Madagaskar), Amerika Selatan dan Tengah(Astuti, 1989). Buah pisang merupakan salah satu komoditas hortikultura yang banyak digemari oleh semua kalangan masyarakat, dari anak-anak hingga dewasa. Buah pisang merupakan sumber vitamin, mineral, serat, yang memiliki banyak manfaat bagi kesehatan. Kandungan gizi yang terdapat dalam setiap $100 \mathrm{~g}$ buah pisang terdiri atas 88 kalori, protein $1,2 \mathrm{~g}$, lemak $0,2 \mathrm{~g}$, karbohidrat $23 \mathrm{~g}$, serat $0,7 \mathrm{~g}$, kalsium $8 \mathrm{mg}$, fosfor $28 \mathrm{mg}$, besi $0,5 \mathrm{mg}$, vitamin A 44 $\mathrm{mg}$, vitamin B 0,04 mg, vitamin C $78 \mathrm{mg}$, dan air $75 \mathrm{~g}$ (Mulyati, 2005). Buah pisang dapat dikonsumsi sebagai buah segar atau diolah menjadi makanan ringan atau produk lainnya.

Jenis pisang konsumsi terdiri atas beberapa jenis seperti, pisang cavendish, pisang ambon hijau, pisang raja, pisang mas, pisang susu, pisang kapok, pisangtanduk, pisang nangka, pisang kapas, pisang uli, dan pisang raja bulu. Pisang yangmenjadi primadona dalam usaha agribisnis adalah pisang cavendish, sekaligus menjadi komoditas ekspor dalam bentuk buah- buahan segar sehingga dapat dijadikan sumber devisa Negara. Pisang cavendishbanyak mengandung dopamine, suatu senyawa katekin (galokatekin). Katekin mampu menurunkan mutagenesitas terhadap beberapa mutagen lingkungan, seperti asap rokok maupun ekstrak tembakau serta secara signifikan mampu menunda onset tumor sehingga pisang disebut sebagai makanan antioksidan alami. Pisang cavendish dikonsumsi oleh $80 \%$ konsumen pisang di luar negeri dan merupakan salah satu jenis pisang yang dibudidayakan secara komersial di Indonesia. Pisang cavendish berasal dari Brasil dan masuk ke Indonesia pada tahun 1990-an (Kaleka, 2013).

Pada tahun 2010, produksi pisang di Indonesia mencapai 5,8 juta ton atau sekitar $30 \%$ dari produksi buah nasional.Namun sejak tahun 2000 terjadi penurunan ekspor yang cukup signifikan, menurut data Badan Pusat Statistik (2012), dari 70.056 ton pada tahun 1999, turun menjadi 2.105 ton pada tahun 2000, bahkan pada tahun 2002 hanya sebesar 512 ton.

Penyebab terjadinya penurunan ekspor disebabkan kualitas buah pisang di Indonesia kurang baik, salah satu penyebab terjadinya penurunan kualitas buah pisang adalah serangan hama dan penyakit pasca panen. Salah satu penyakit yang biasanya menyerang buah pisang pasca panen dan simpanan adalah penyakit 
antraknosa yang disebabkan oleh Colletotrichum musae (Semangun, 1996 ; Soesanto, 2008; Martoredjo, 1995). Penyakit antraknosa menyebabkan infeksi pada sisir buah melalui luka karena pemotongan sisir dari tangkai tandan yang menyebabkan pembusukan pada tangkai buah dan buah-buah terlepas. Kerusakan pada buah yang cepat akan mempengaruhi tampilan fisik buah sehingga berpengaruh pula terhadap mutu buah serta menurunkan harga komersial.

Perkembangan antraknosa pada pisang dapat diatasi dengan penggunaan fungisida sintetis, namun, cara tersebut kurang berwawasan lingkungan dan dapat menimbulkan dampak negatif. Penggunaan fungisida secara intensif dan terus menerus dapat menimbulkan terjadinya resistensi patogen, terbunuhnya makhluk hidup bukan sasaran, residu pada bahan makanan, dan pencemaran terhadap lingkungan serta membahayakan manusia. Oleh karena itu, perlu upaya pengendalian pilihan yang relatif lebih aman, yaitu dengan pemanfaatan agensia antagonis.Pengendalian ini diharapkan lebih efektif dan ramah lingkungan.Salah satu agensia antagonis yang sering diteliti dan memberikan potensi yang cukup baik adalah Trichoderma spp.

\section{METODE PENELITIAN}

Penelitian ini dilakukan di Laboratorium Penyakit Tumbuhan, Fakultas Pertanian, Universitas Lampung. Penelitian ini dilaksanakan pada bulan Mei 2014 sampai dengan Juni 2014. Alat-alat yang diperlukan untuk penelitian ini adalah mikroskop stereo, mikroskop majemuk, kaca preparat dan kaca penutup, tabung erlenmayer, tabung reaksi, cawan petri, autoclave, timbangan listrik, mikropipet, lampu bunsen, kertas alumunium foil, plastic cling wrap, nampan plastik, bor gabus, spatula dan jarum ose.

Bahan-bahan yang digunakan dalampenelitian ini adalah, buah pisang cavendish 240 buah, isolat T.viride, T. harzianum, T. koningii dan isolat $C$. musae, media potato dextrose agar (PDA), asam laktat, alkohol 70\%, spritus, dan aquades.Percobaan ini disusun dalam Rancangan Acak Lengkap (RAL) dengan 4 perlakuan dan 6 ulangan.Perlakuan terdiri dari kontrol (P0), aplikasi T. viride ( $\mathrm{P} 1)$, T. harzianum $(\mathrm{P} 2)$, dan T. koningii $(\mathrm{P} 3)$. Percobaan dilaksanakan secara In vitro dan secara In vivo. Percobaan In vitro adalah untuk mengetahui pengaruh Trichodermaspp. dalam menghambat pertumbuhan koloni jamur $C$. musae. Sedangkan percobaan In vivo adalah untuk mengetahui pengaruh Trichodermaspp. terhadap intensitas penyakit antraknosa yang disebabkan oleh $C$. musae pada buah pisang cavendish.Data yang diperoleh dianalisis dengan menggunakan sidik ragam (Anova) yang dilanjutkan dengan Uji Beda Nyata Terkecil (BNT) pada taraf nyata $1 \%$.

\section{Pelaksanaan percobaan in vitro}

Penyiapan isolat $C$. musae. Penyiapan biakan murni C. musae dilakukan di Laboratorium Penyakit Tumbuhan. Biakan jamur C.musae di isolasi dari buah pisang cavendish sebelumnya yang telah terserang penyakit antraknosa. Untuk mendapatkan biakan murni, dilakukan proses penumbuhan ulang ke media PDA dalam cawan petri. Buah pisang yang terserang antraknosa kemudian di kupas dan dipotong berbentuk dadu $( \pm 0,5 \times 0,5 \mathrm{~cm})$. potongan dadu tubuh buah tersebut selanjutnya direndam dalam larutan klorok $0,5 \%$ selama lima 1 menit, lalu ditiriskan (kering angin). Setelah kering,tiga buah potongan dadu diletakkan dalam cawan yang berisi media PDA. Selanjutnya isolat C.musae yang tumbuh dimurnikan kembali dalam media PDA yang lain (Gambar 1).

Penyiapan isolat Trichoderma spp. Isolat Trichoderma spp. yang yang terdapat pada Laboratorium Penyakit Tumbuhan, Fakultas Universitas Lampung, Trichoderma spp.diperbanyak dan dibiakkan pada media PDA, kemudian biakan yang tumbuh dimurnikan dan identifikasi berdasarkan ciri-ciri morfologi jamur baik secara makroskopis maupun mikroskopis, sehingga diketahui biakan murni T. viride, T. harzianum, dan T. koningii (Gambar 2).

Pengujian kemampuan Trichoderma spp. sebagai agen antagonis secarain vitro.Pengujian dilakukan pada media PDA dalam cawan petri.Pada bagian bawah cawan dibuat garis tengah yang saling tegak lurus. Kemudian pada garis horizontal ditandai 2 titik yang masing-masing berjarak $3 \mathrm{~cm}$ dari tepi cawan untuk meletakkan biakan murni $C$. musae dan biakan murni jamur Trichoderma spp. (dual culture method). Setelah itu, cawan petri berisikan biakan murni $C$. musae dan Trichoderma.sppdiinkubasi pada suhu ruang selama 6 hari.

\section{Pelaksanaan percobaaninvivo}

Penyiapan buah pisang. Pada penelitian ini setiap perlakuan menggunakan 10 buah pisang yang belum matang, sehingga jumlah keseluruhan sebanyak 240 buah, buah pisang yang telah dicuci bersih kemudian didisinfeksi dengan menyemprotkan alkohol $70 \%$ kebagian permukaan buah. Kemudian buah pisang 

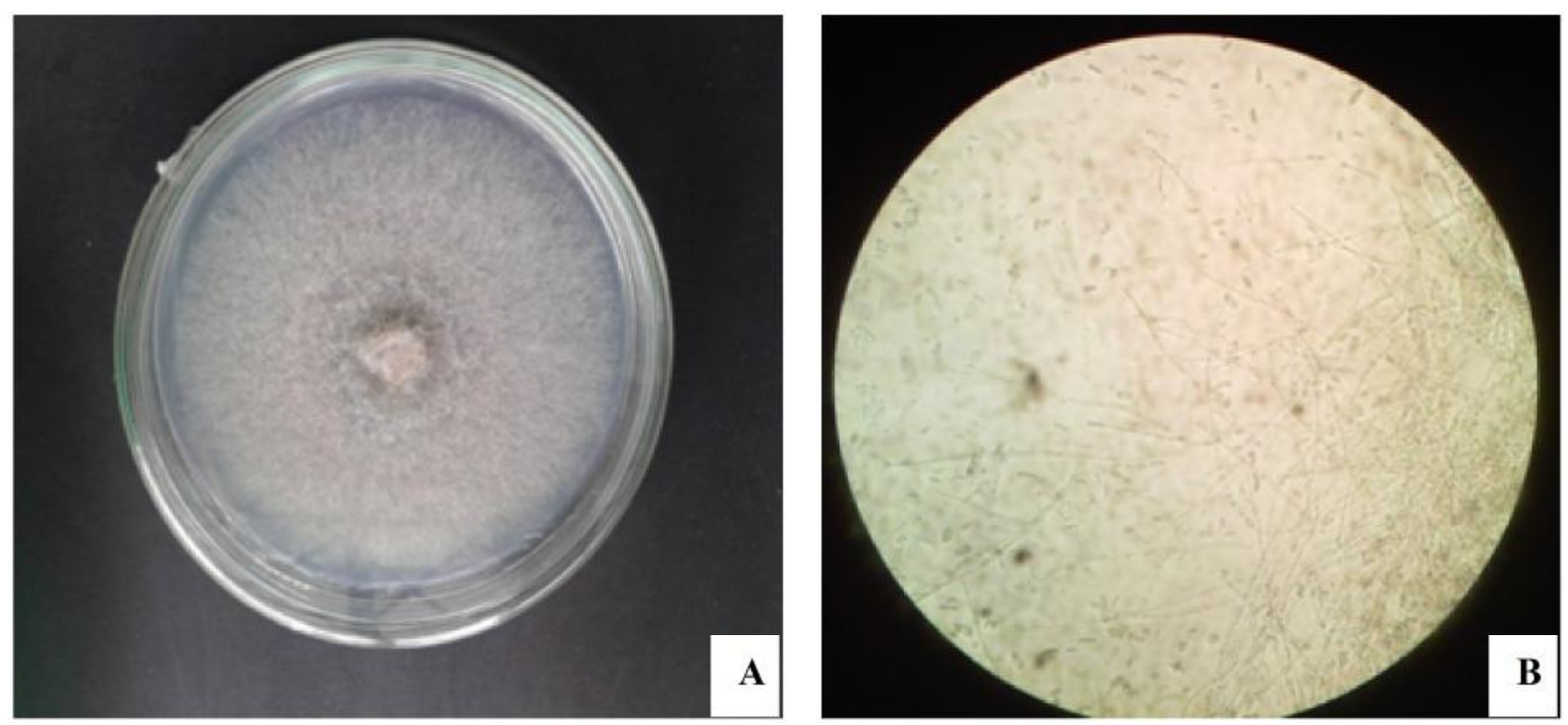

Gambar 1. (A) Koloni jamur Colletotrichum musae dalam cawan petri pada 18 hari setelah isolasi; (B) MorfologiColletotrichum musae dibawah mikroskop dengan perbesaran 400x
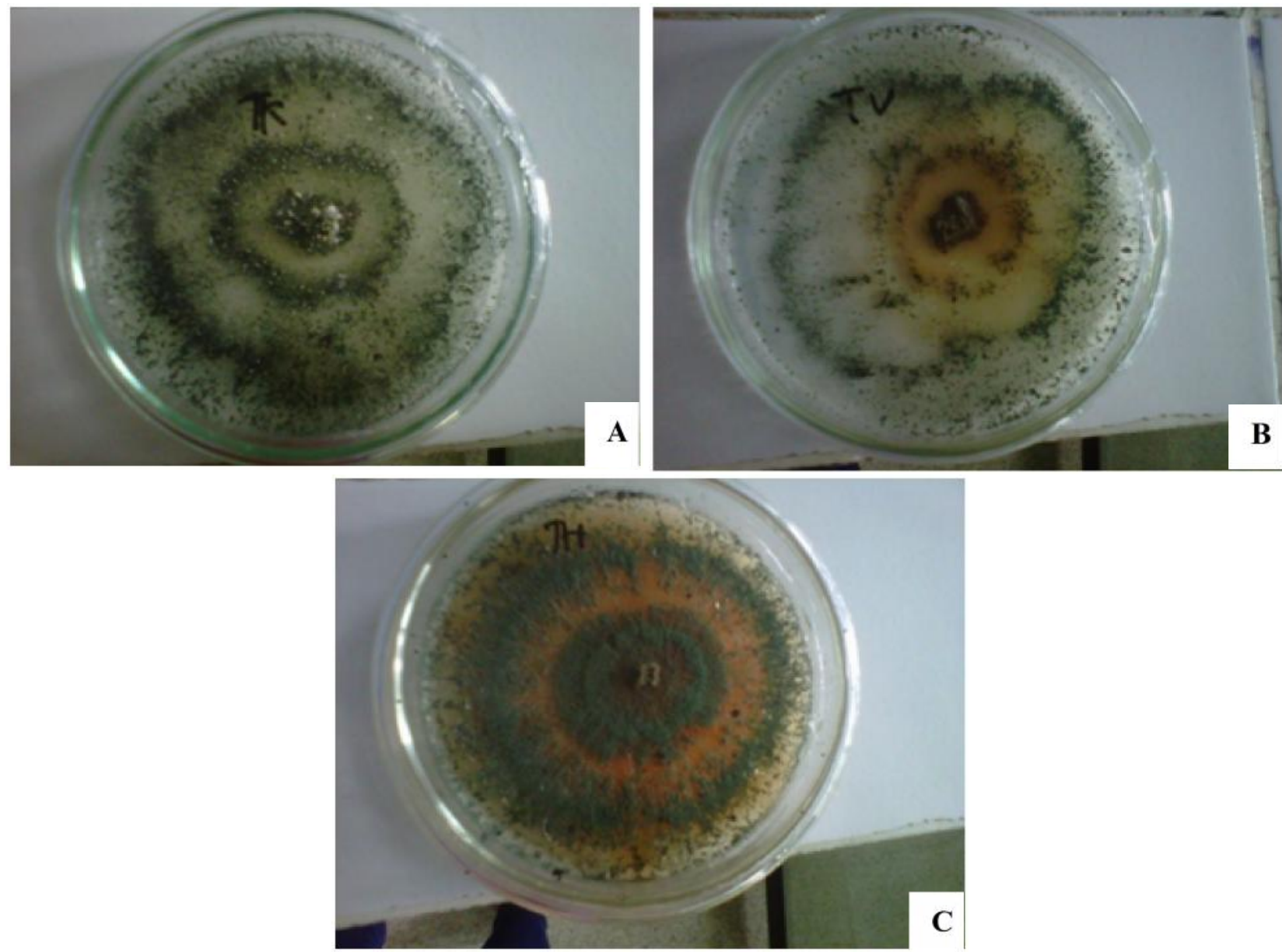

Gambar 2. Koloni jamur Trichoderma dalam cawan petri pada 7 hari setelah isolasi. (A) T. koningii, (B) $T$. viride, (C) T. harzianum. 
dimasukkan kedalam masing-masing nampan plastik berukuran $3 \times 30 \mathrm{~cm}$.

Penyiapan suspensi Trichoderma spp. Pembuatan suspensi Trichoderma spp. dilakukan dengan cara biakan Trichoderma spp. diberi 10 (sepuluh) ml aquades steril ke dalam beaker glass, sehingga didapat kerapatan spora $37 \times 10^{6} \mathrm{spora} / \mathrm{ml}$

Penyiapan suspensi $C$.musae.Pembuatan suspensi $C$. musae dilakukan dengan cara 1 (satu) petri biakan $C$. musae yang telah berumur 7 (tujuh) hari diberi $10 \mathrm{ml}$ (sepuluh mili liter) aquades kedalam tabung reaksi sehingga didapat kerapatan spora $1,37 \times 10^{6}$ spora per $\mathrm{ml}$.

\section{Aplikasi C.musae dan Trichoderma spp secara in} vivo.Aplikasi Trichoderma spp. dan C. musae pada buah pisang dilakukan dengan menggunakan hand sprayer dengan cara menyemprotkan suspensi inokulum Trichoderma dan C.musae secara langsung keseluruh pada permukaan buah pisang, Trichodermaspp disemprotkan terlebih dahulu dan di keringkan \pm 1 menit, kemudian berikutnya di inokulasi dengan suspensi $C$. musae. Buah pisang diletakkan di atas nampan yang ditutup plastik wrap dan kemudian di inkubasi pada ruang dengan suhu kamar.

Pengamatan Percobaan in vitro, variabel yang diamati adalahpersentase penghambatan pertumbuhan koloni jamur C.musae pada media PDA.Persentase penghambatan ditentukan dengan rumus sebagai berikut persentase daerah penghambatan :

$$
\frac{\mathrm{r}_{1}-\mathrm{r}_{2}}{\mathrm{r}_{1}} \times 100 \%
$$

Keterangan:

$\mathrm{r}_{1}=$ Jari-jari koloni $C$. musae yang kearah menjauhi Jamur Trichodermaspp. $\mathrm{r}_{2}=$ Jari-jari koloni $C$. musae yang menuju/mendekati jamur Trichoderma spp

Pengamatan percobaan in vivo, variable yang diamati adalah keparahan penyakit (KP) dihitung dengan rumus :

$$
\mathrm{KP}=\frac{\text { Luas gejala }}{\text { Luas keseluruhan buah }} \times 100 \%
$$

Luas Gejala ialah luas gejala yang telah digambar diatas plastik wrapping pada permukaan buah pisang. Luas keseluruhan buah ialah Luas plastik wrapping yang membungkus permukaan buah pisang. Pengamatan dihentikan apabila data yang diperoleh sudah mencapai titik konstan.

\section{HASIL DAN PEMBAHASAN}

\section{Pengaruh Trichoderma spp. terhadap pertumbuhan} C. musae secara In Vitro. Berdasarkan analisis ragam, terlihat bahwa perlakuan Trichoderma koningii, Trochoderma viridedan Trichoderma harzianum menunjukkan pengaruh yang sangat nyata terhadap pertumbuhan $C$. musae secara in vitro.

Setelah dilakukan pengujian lanjutan dengan uji BNT pada taraf $1 \%$, pengaruh perlakuan beberapa spesies Trichoderma terhadap pertumbuhan $C$. musaemenunjukkan hasil tidak berbeda nyata satu sama lain, kecuali jika dibandingkan dengan kontrol (Tabel $1)$.

Dari Tabel 1, C. musaetanpa perlakuan atau kontrol, mempunyai rerata jari-jari $(\mathrm{cm}) 1,25$ pada 3 hsa dan $1,30 \mathrm{~cm}$ pada $6 \mathrm{hsa}$, sedangkan rerata jari-jari pertumbuhan C. musae yang diantagoniskan dengan beberapa spesies Trichoderma hanya dapat tumbuh berkisar antara $1,15-1,18 \mathrm{~cm}$ hingga $1,17-1,21$ pada 6 hsa.

Tabel 1. Pengaruh aplikasi beberapa spesies Trichoderma terhadap pertumbuhan jamur C. musae

\begin{tabular}{lcc}
\hline \multirow{2}{*}{ Perlakuan } & \multicolumn{2}{c}{ Rerata jari-jari $(\mathbf{c m})$ pada hari ke- } \\
\cline { 2 - 3 } & $\mathbf{3 ~ h s a}$ & $\mathbf{6 ~ h s a}$ \\
\hline Kontrol & $1,25 \mathrm{a}$ & $1,30 \mathrm{a}$ \\
T. koningii & $1,18 \mathrm{~b}$ & $1,21 \mathrm{~b}$ \\
T. viride & $1,16 \mathrm{~b}$ & $1,19 \mathrm{~b}$ \\
T. harzianum & $1,15 \mathrm{~b}$ & $1,17 \mathrm{~b}$ \\
\hline Nilai F 0,01 & $21,39^{\mathrm{sn}}$ & $31,26^{\mathrm{sn}}$ \\
\hline
\end{tabular}

Keterangan : Angka dalam kolom yang diikuti huruf berbeda menunjukan perbedaan yang nyata pada uji BNT taraf $1 \%$. Data hasil transformasi $\sqrt{+} 0,5$. hsa $=$ hari setelah apliaksi. 
Pengaruh perlakuan terhadap persentase penghambatan T. koningii, T. viride, dan T. harzianum pada pengamatan 3 dan 6 hsa juga menunjukkan pengaruh yang sangat nyata (Tabel 2). Hasil penelitian menunjukkan bahwa perlakuan bahwa T. koningii, $T$. viride, dan T. harzianumefektif menekan pertumbuhan C. musae secara in vitro, dan tidak terdapat perbedaan yang nyata antara perlakuan Trichoderma.

Keparahan penyakit antraknosa pada buah pisang. Berdasarkan analisis ragam, menunjukkan bahwa perlakuan beberapa spesies Trichoderma berpengaruh sangat nyata terhadap tingkat keparahan penyakit antraknosa pada buah pisang (Tabel 3).

Hasil uji lanjut dengan BNT menunjukkan bahwa perlakuan T. koningii, T. viride, dan T. harzianum mempunyai pengaruh yang sama dalam menekan tingkat keparahan penyakit antraknosa pada buah pisang. Masing-masing spesies memiliki kemampuan yang sama dan efektif menekan keparahan penyakit antraknosa pada buah pisang.
Dari Gambar 3 dapat dilihat, keparahan penyakit pada perlakuan kontrol meningkat dengan cepat, sedangkan perlakuan pada beberapa spesies Trichoderma terlihat lambat dari hari ke 6 hingga hari ke 10 setelah aplikasi (Gambar 4).

Hasil penelitian menunjukkan bahwa perlakuan T. koningii, T. viride, dan T. harzianum mampu menekan pertumbuhan koloni jamur C. musae secara in vitro. Mekanisme penghambatan yang terjadi diduga melalui mekanisme antibiosis yang ditandai dengan terbentuknya zona bening yang merupakan zona penghambatan pertumbuhan $C$. musae pada percobaan in vitro (Gambar 5,6 \& 7). Menurut Vey et al. (2001), senyawa antibiotik tersebut mempengaruhi dan menghambat banyak sistem fungsional dan membuat patogen rentan. Sedangkan mekanisme penghambatan yang lain, yaitu kompetisi nutrisi dan hiperparasit tidak ditemukan dalam hasil penelitian ini. Karena pada media PDA telah tersedia nutrisi yang cukup untuk pertumbuhan dan perkembangan jamur, sedangkan hiperparasit tidak terjadi karena Trichoderma tidak menembus dinding sel dan masuk kedalam sel untuk

Tabel 2. Pengaruh beberapa spesiesTrichoderma terhadap persentase pertumbuhan jamur C. musae

\begin{tabular}{lcc}
\hline & \multicolumn{2}{c}{ Rerata jari-jari $(\mathbf{c m})$ pada hari ke- } \\
\cline { 2 - 3 } Perlakuan & $\mathbf{3}$ hsa & $\mathbf{6 ~ h s a}$ \\
\hline Kontrol & $0 \mathrm{a}$ & $0 \mathrm{a}$ \\
T. koningii & $50 \mathrm{~b}$ & $53 \mathrm{~b}$ \\
T. viride & $62 \mathrm{~b}$ & $63 \mathrm{~b}$ \\
T. harzianum & $74 \mathrm{~b}$ & $75 \mathrm{~b}$ \\
\hline Nilai F 0,01 & $21,39^{\mathrm{sn}}$ & $31,26^{\mathrm{sn}}$ \\
\hline
\end{tabular}

Keterangan : Angka dalam kolom yang diikuti huruf berbeda menunjukan perbedaan yang nyata pada uji BNT taraf $1 \%$. Data hasil transformasi $\sqrt{\mathrm{x}}+0,5$. hsa $=$ hari setelah apliaksi.

Tabel 3. Pengaruh beberapa spesies Trichoderma terhadap intensitas penyakit antraknosa pada buah pisang

\begin{tabular}{lccccc}
\hline \multirow{2}{*}{ Perlakuan } & \multicolumn{5}{c}{ Keparahan Penyakit(\%) } \\
\cline { 2 - 6 } & $\mathbf{6}$ hsa & $\mathbf{7}$ hsa & $\mathbf{8 ~ h s a}$ & $\mathbf{9}$ hsa & $\mathbf{1 0}$ hsa \\
\hline kontrol & $9,85 \mathrm{a}$ & $16,36 \mathrm{a}$ & $24,96 \mathrm{a}$ & $49,83 \mathrm{a}$ & $72,26 \mathrm{a}$ \\
$T$. viride & $1,11 \mathrm{~b}$ & $2,10 \mathrm{~b}$ & $3,93 \mathrm{~b}$ & $5,16 \mathrm{~b}$ & $23,11 \mathrm{~b}$ \\
$T$. harzianum & $0,72 \mathrm{~b}$ & $1,42 \mathrm{~b}$ & $2,16 \mathrm{~b}$ & $2,08 \mathrm{~b}$ & $20,25 \mathrm{~b}$ \\
$T$ koningi & $1,12 \mathrm{~b}$ & $2,66 \mathrm{~b}$ & $9,63 \mathrm{~b}$ & $16,07 \mathrm{~b}$ & $36,08 \mathrm{~b}$ \\
\hline Nilai F 0,01 & $\mathbf{1 0 , 0 6}^{\text {sn }}$ & $\mathbf{4 4 , 4 3}^{\text {sn }}$ & $\mathbf{7 , 3 6}^{\text {sn }}$ & $\mathbf{9 , 4 6}^{\text {sn }}$ & $\mathbf{6 , 3 0}^{\text {sn }}$ \\
\hline
\end{tabular}

Keterangan : Angka dalam kolom yang diikuti huruf berbeda menunjukan perbedaan yang nyata pada uji BNT taraf $1 \%$. Data hasil transformasi $\sqrt{\mathrm{x}}+0,5$. hsa $=$ hari setelah apliaksi. 


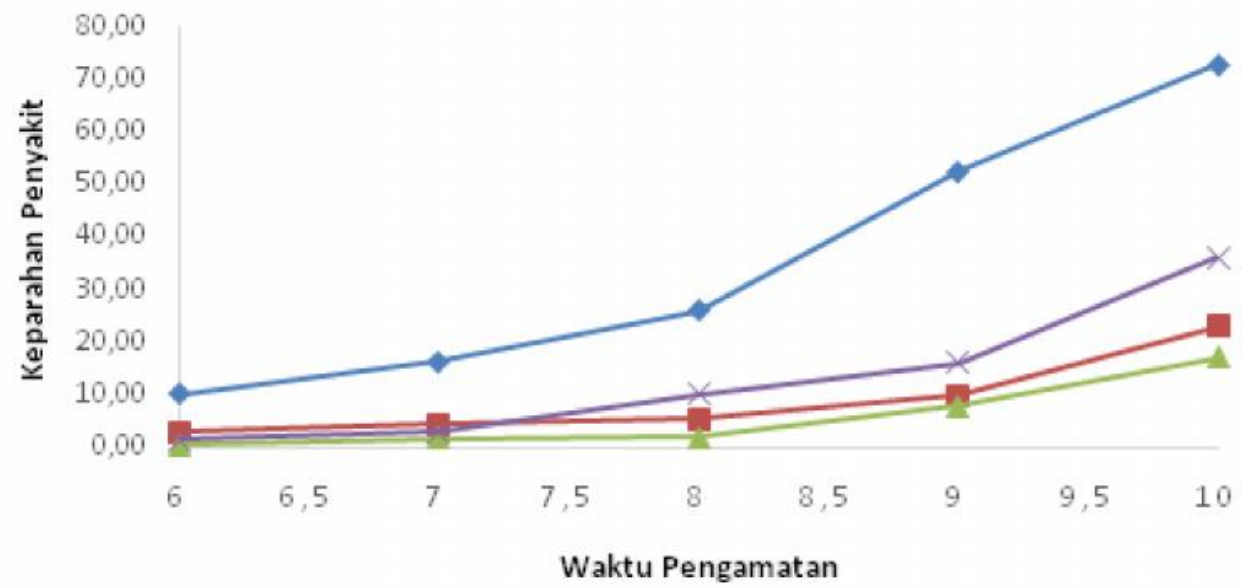

Gambar 3. Pengaruh Trichoderma terhadap perbedaan perkembangan penyakit antraknosa. $+=$ kontrol, 4 $=$ T. Viride, $\rightarrow=T$. Harzianum, $\rightarrow=T$. koningii.
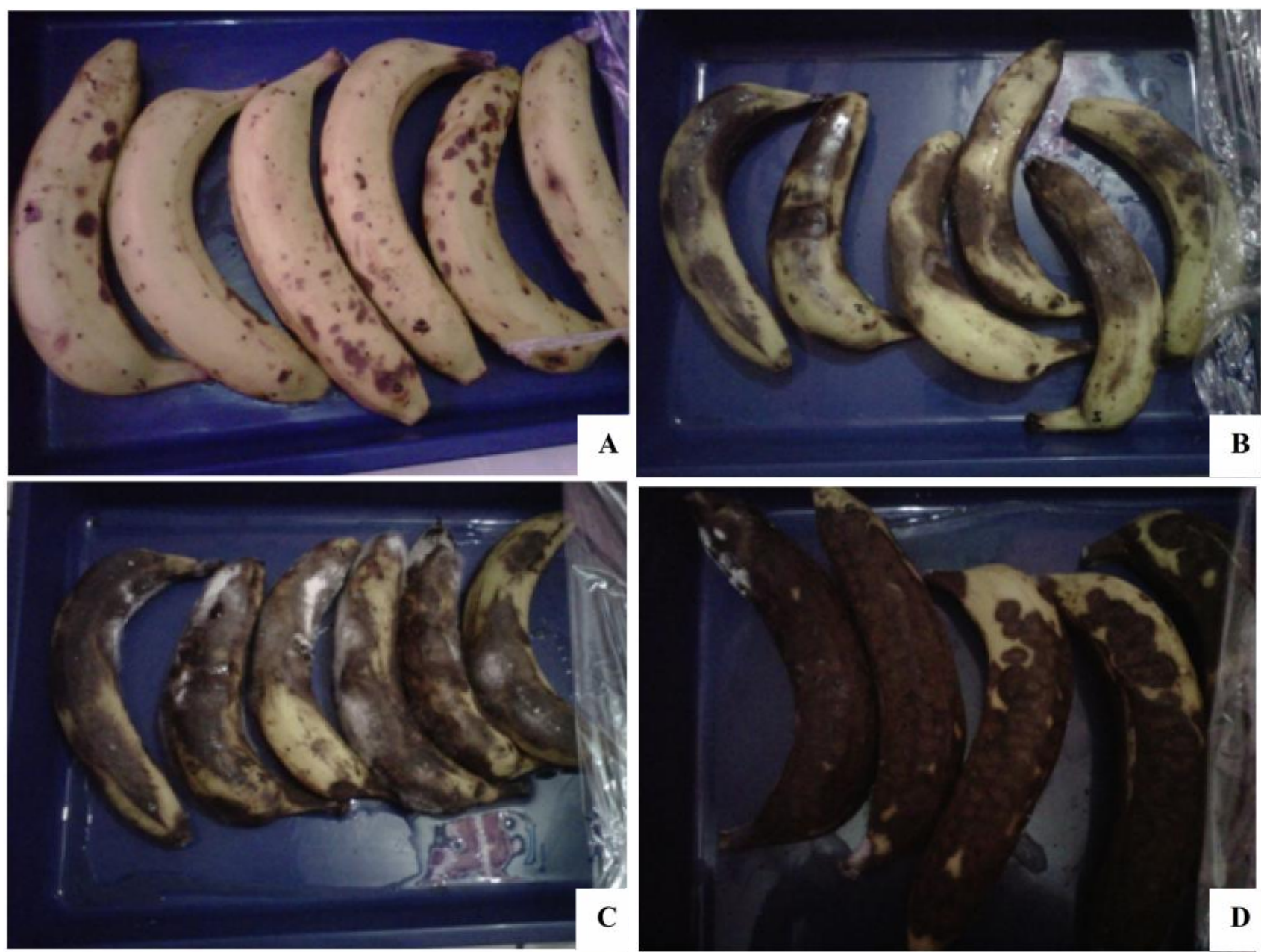

Gambar 4. Pengamatan aplikasi Trichoderma pada hari ke 10 pada percobaan in vivo. (A) T. harzianum; (B) T. viride; (C) T. koningii; (D) Kontrol. 


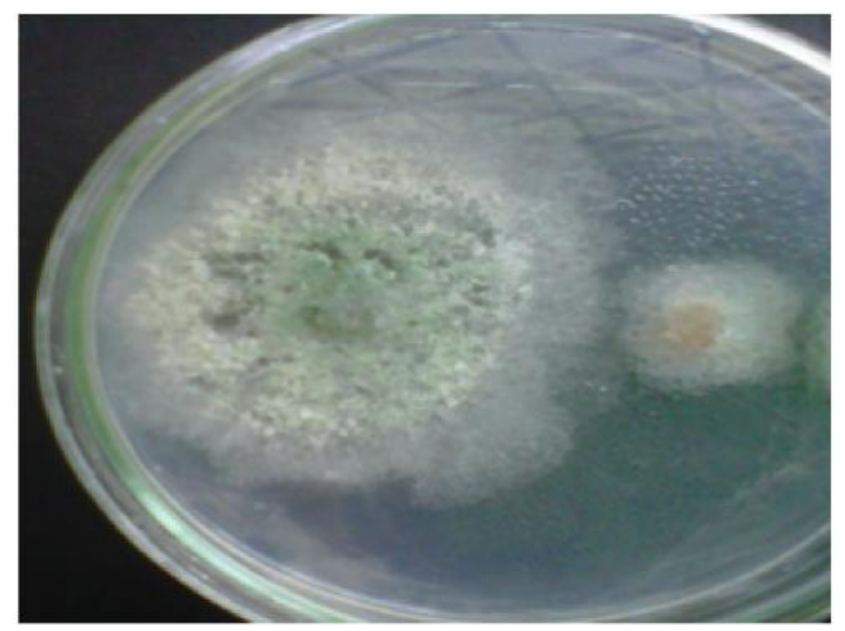

Gambar 5. Antagonisme antara jamur Colletotrichum musae (koloni pink) dengan jamur Trichoderma koningii

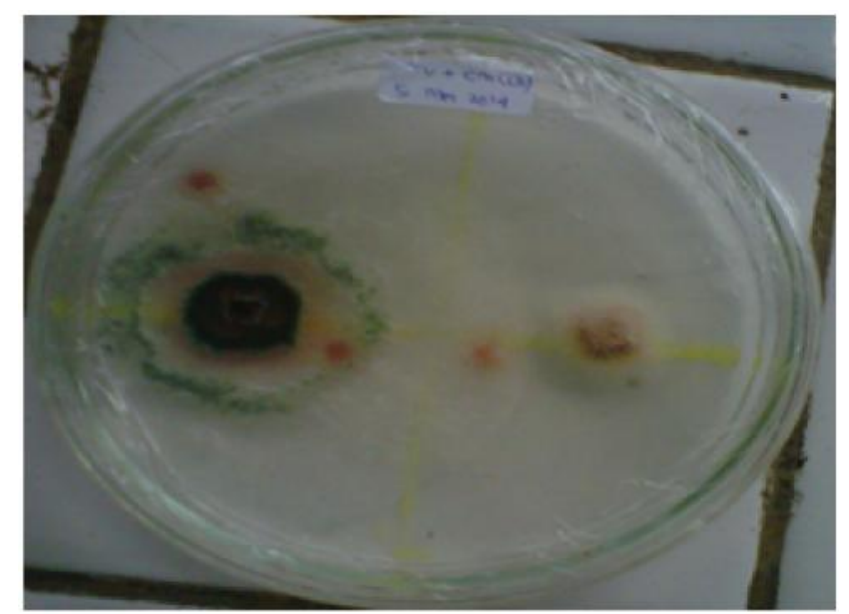

Gambar 6. Antagonisme antara jamur Colletotrichum musae (koloni pink) dengan jamur Trichoderma viride

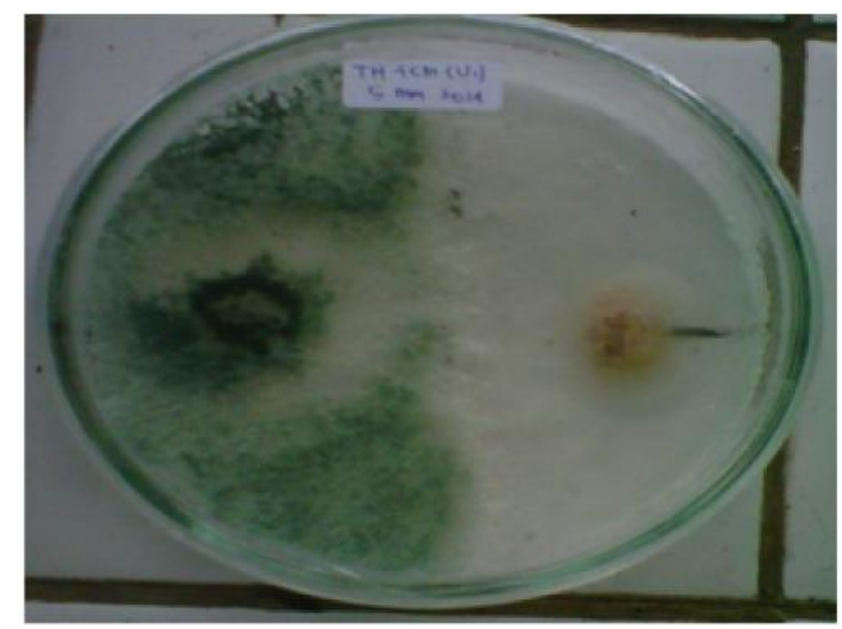

Gambar 7. Antagonisme antara jamur Colletotrichum musae (koloni pink) dengan jamur Trichoderma harzianum 
mengambil zat makanan dari dalam sel. Hal ini sejalan dengan penelitian Nurhayati (2001) mekanisme penghambatan dari Trichoderma spp. terhadap infeksi $S$. roflsii dapat terjadi melalui beberapa mekanisme di antaranya dengan memproduksi senyawa glutoksin dan viridian yang bersifat toksik terhadap jamur lain.

Jamur antagonis T. koningii dalam mekanisme antagonismenya membentuk senyawa dengan sifat mikostatis dan juga senyawa anti jamur. $T$. koningii mampu berperan sebagai agensia penekan terhadap patogen berbahaya, seperti Gaeunanomyces gramis var. tritici pada gandum (Soesanto, 2008).

T. viride mempunyai keaktifan antibiotika terkuat dibandingkan T. koningii dan T. harzianum. Antibiotika yang telah dideteksi adalah seskuiterpena trichodermin, popipeptida berdaur, peptida trichotoksin A berdaur, peptida suzukasilin, dan asam dermadin monobasa (Soesanto, 2008).

Selanjutnya, perlakuan T. koningii, T. viride, dan T. harzianumdalam menekan intensitas penyakit antraknosa pada buah pisang cavendish, menunjukkan kemampuan menghambat pertumbuhan koloni jamur $C$. musae. Hal ini sejalan dengan hasil penelitian Nurhaedah (2002), tentang pengaruh aplikasi Trichoderma spp. terhadap persentase serangan penyakit antraknosa pada buah cabai merah besar. Perlakuan Trichoderma spp. berpengaruh nyata terhadap persentase serangan penyakit antraknosa. Hal tersebut dibuktikan dengan rendahnya persentase serangan penyakit pada perlakuan Trichoderma spp. Terjadinya penurunan persentase serangan penyakit berarti bahwa Trichoderma spp. telah mampu menekan pertumbuhan patogen antraknosa. Hal ini diduga disebabkan oleh pertumbuhan yang cepat dan adanya sifat antagonis dari Trichoderma spp.

Hasil pengujian baik secara ini vitro maupun secara in vivo, pertumbuhan $C$. musae yang diberi perlakuan beberapa spesies Trichoderma menunjukkan hasil yang tidak berbeda nyata satu sama lain, atau memiliki kemampuan yang sama dalam menghambat pertumbuhan $C$. musae. Kemampuan dan mekanisme Trichoderma dalam menghambat pertumbuhan patogen secara rinci bervariasi pada setiap spesiesnya. Perbedaan kemampuan ini disebabkan oleh faktor ekologi yang membuat produksi bahan metabolit yang bervariasi pula.

Berdasarkan hasil penelitian ini menunjukkan bahwa semua isolat Trichoderma spp.memiliki kemampuan yang sama dalam menghambat pertumbuhan patogen $C$. musae baik pada percobaan in vitro maupun percobaan in vivo.

\section{KESIMPULAN}

Dari penelitian ini dapat disimpulkan bahwa (1) T. viride, T. koningii, dan T. harzianum efektif menghambat pertumbuhan koloni jamur C. musae dan masing-masing spesies Trichodermaspp. memiliki kemampuan yang sama dalam menekan pertumbuhan koloni jamur C. musae secara in vitro. (2) T. viride, $T$. koningii, dan T. harzianum efektif menekan intensitas penyakit antraknosa yang disebabkan $C$. musaedan masing-masing spesies Trichodermaspp. memiliki kemampuan yang sama dalam menekan pertumbuhan koloni jamur $C$. musae pada buah pisang cavendish.

\section{DAFTAR PUSTAKA}

Astuti, S. 1989. Manfaat Buah Pisang. Sinar Tani, Bandung.Badan Pusat Statistik. 2012. Produksi Buah-buahan di Indonesia. www.bps.go.id.Akses pada tanggal 11 Maret 2014.

Baharia, S. 2000. Uji Antagonis Beberapa Isolat Cendawan Trichoderma Terhadap Pertumbuhan Colletotrichum capsici pada Buah Cabai.Skripsi Fakultas Pertanian UNTAD, Palu.

Graham,K.M. 1971. Plant Diseases of Fiji.Min. Overseas Dev., Overseas Res. Publ. 17, London, $250 \mathrm{p}$.

Gultom, J.M. 2008. Pengaruh Pemberian Beberapa Jamur Antagonis dengan Berbagai Tingkat Konsentrasi Untuk Menekan Perkembangan Jamur Phytium sp Penyebab Rebah Kecambah pada Tanaman Tembakau (Nicotiana tabaccum L.) http://repository.usu.ac.id.pdfAkses 05 Oktober 2014.

Kaleka N.2013.Pisang-pisang Komersial. Areita. Surakarta.

Martoredjo, T. 1995.Virulensi beberapa isolat Colletotrichum musae terhadap buah pisang dan ketahanan beberapa buah kultivar pisang terhadap C. musae.J. Perlind. Tan.Indon. 1 (1): 33-37.

Mulyati, S. 2005. Teknologi Pangan. Trubus Agri Sarana, Surabaya.

Nurhaedah. 2002. Pengaruh Aplikasi Trichoderma sp. dan Mulsa Terhadap Persentase Serangan Penyakit Antraknosa pada Buah Tanaman CabaiMerah Besar (Capsicum annum L). Skripsi Fakultas Pertanian UNTAD,Palu. 
Nurhayati, H. 2001. Pengaruh Pemberian Trichoderma sp. Terhadap Daya Infeksi dan Ketahanan Hidup Sclerotium rolfsii pada Akar Bibit Cabai. Skripsi Fakultas Pertanian UNTAD, Palu.

Semangun,H. 1996. Ilmu Penyakit Tumbuhan. Gadjah Mada University Press. Yogyakarta.

Soesanto,L. 2008. Pengantar Pengendalian Hayati Penyakit Tanaman. PT Raja Grafindo Persada. Jakarta.

Sulistyowati, L. Estiejarini, M., \&Cholil, A. 1997. Tehnik Isolat Trichoderma spp. Sebagai Agen Pengendali Hayati Sclerotium roflsii Sacc. Pada Tanaman Kacang Tanah.Lembaga Penelitian, Universitas Brawijaya,Malang.
Sunarjono, H.2004. Budidaya Pisang dengan Bibit Kultur Jaringan. Penebar Swadaya. Jakarta.

Suyanti, A.S.2010.Pisang Budidaya, Pengolahan dan Prospek Pasar (Edisi Revisi). Penebar Swadaya. Jakarta.

Vey, A., R, E., Hoagland \& Butt. T.M. 2001. Fungi as Biocontrol Agents: Progress problems and potential. In Butt, T. M., C. Jackson and N. Magan (Ed). Toxic metabolite of fungal biocontrol agents. Publishing CAB International. London. 